\title{
Outcomes of Roux-en-Y gastric bypass surgery for severely obese patients with type I diabetes: a case series report
}

This article was published in the following Dove Press journal: Diabetes, Metabolic Syndrome and Obesity:Targets and Therapy 9 August 2010

Number of times this article has been viewed

\author{
Carlos E Mendez \\ Robert J Tanenberg \\ Walter Pories \\ Diabetes and Obesity Institute, \\ East Carolina University, \\ Greenville, NC, USA
}

Correspondence: Robert J Tanenberg East Carolina University, 600 Moye Blvd 3E-129, Greenville, NC 27834, USA

Email tanenbergr@ecu.edu

\begin{abstract}
Roux-en-Y gastric bypass surgery (RYGB) reverses type 2 diabetes (DM2) in approximately $83 \%$ of patients with morbid or severe obesity. This procedure has been performed in small numbers of severely obese patients with type 1 diabetes (DM1), but the impact on glycemic control and insulin requirement in this population has not been widely described. We report three patients with DM1 and severe obesity that underwent RYGB. Weight, glycemic control, and insulin requirements before and one year after the procedure were compared. Significant weight loss was achieved by all three patients but insulin requirements decreased in only 2 patients. In contrast, glycemic control (A1C) remained suboptimal in all three patients up to one year after the surgery. These findings suggest that RYGB leads to important weight loss and positively affects insulin sensitivity. However, reaching optimal glycemic control in patients with DM1 diabetes remains challenging due to persisting insulin deficiency.
\end{abstract}

Keywords: gastric bypass, Roux-en-Y, obesity, diabetes, insulin

\section{Introduction}

Obesity is commonly found in patients with type 2 diabetes (DM2). This growing epidemic has also affected populations with type 1 diabetes (DM1). Recently, the prevalence of obesity in the United States among young patients (3-19 years old) with DM1 was found to be over $12 \% .{ }^{1}$ For patients with DM2 and morbid or severe obesity, defined as body mass index (BMI) over $40 \mathrm{~kg} / \mathrm{m}^{2}$, bariatric surgery has resulted in reversal of type $2 \mathrm{DM}$ in approximately $83 \%$ of cases. ${ }^{2}$ Of the available bariatric surgical techniques, diabetes reversal ranges from $66 \%$ after gastric banding to $95 \%$ with the biliopancreatic diversion with duodenal switch (BPD). ${ }^{3}$ There is increasing evidence that in addition to caloric restriction, significant changes in secretion of gut peptides or incretins occur with surgery leading to important enhancement of insulin production and utilization. ${ }^{4}$

In contradistinction to DM2, results of these procedures in severely obese patients with DM1 are limited. Czupryniak et al presented two cases of severely obese patients with DM1 who underwent Roux-en-Y gastric bypass surgery (RYGB). They reported remarkable improvement of glycemic control based on a decrease in glycosylated hemoglobin (A1C) of $9.5 \%$ to $5.7 \%$ in the first case and $10.4 \%$ to $7.3 \%$ in the second case. These authors suggested that RYGB led to improvement in insulin resistance, favorably affecting glycemic control. Nevertheless, insulin therapy was still required after 2 years in both cases although the insulin requirement decreased from 0.6 units $/ \mathrm{kg}$ 
to 0.5 units $/ \mathrm{kg}$ in the first case and from 0.95 units $/ \mathrm{kg}$ to 0.78 units $/ \mathrm{kg}$ in the second case. ${ }^{5}$

\section{Case reports}

We retrospectively gathered data on three female patients with the diagnosis of DM1 with severe obesity that electively underwent RYGB. The first patient (Patient A) was a 29-yearold female with a history of DM1 since age 21 . Her diagnosis was confirmed by undetectable C-peptide $(<0.1 \mathrm{ng} / \mathrm{mL})$ and elevated glutamic acid decarboxylase autoantibodies (GAD-65) at $4.1 \mathrm{nmol} / \mathrm{L}$. Since her last pregnancy at age 23, her weight significantly increased to maximum preoperative weight of $115 \mathrm{~kg}$ (BMI $40.6 \mathrm{~kg} / \mathrm{m}^{2}$ ). She was unable to lose weight by lifestyle changes and was successfully screened for RYGB. Her average A1C the year before RYGB surgery reflected poor glycemic control (8.2\%). Insulin was delivered through a continuous subcutaneous infusion system (CSII). Her total daily insulin dose before the surgery was 65.5 units, ( 0.57 units $/ \mathrm{kg}$ ). Within the first month after the RYGB surgery, her insulin requirements decreased to 0.37 units $/ \mathrm{kg}$ without much prandial insulin on a very minimal diet. However, as her diet advanced, prandial insulin doses were reintroduced. One year after the procedure her weight had decreased to $75.5 \mathrm{~kg}$ corresponding to a $34.4 \%$ weight reduction. Her total insulin dose was 45 units $(0.60$ units $/ \mathrm{kg})$. Her average A1C for the year after the surgery decreased to $7.5 \%$.

The second patient (Patient B) was a 62-year-old female who had been diagnosed with DM1 since age 9 . Undetectable C-peptide $(<0.05 \mathrm{ng} / \mathrm{mL})$ was documented in her records confirming her diagnosis. Other comorbidities included depression, dyslipidemia, and history of stroke. She had a preoperative weight of $110.4 \mathrm{~kg}$ (BMI $43.9 \mathrm{~kg} / \mathrm{m}^{2}$ ). Her insulin was delivered through a CSII system. Her total daily insulin dose prior to RYGB was 52.2 units ( 0.47 units $/ \mathrm{kg}$ ). Her average preoperative A1C was $7.6 \%$. One year after the procedure her weight had decreased to $77.5 \mathrm{~kg}$ (29.8\% weight reduction). Her total daily insulin dose had decreased to 35.6 units ( 0.46 units $/ \mathrm{kg}$ ). Her average $\mathrm{A} 1 \mathrm{C}$ for the year after the surgery was $7.8 \%$.

The third patient (Patient C) was a 36-year-old female with a history of DM1 since age 22. Her diagnosis was supported by undetectable C-peptide $(<0.05 \mathrm{ng} / \mathrm{mL})$. She had history of obesity for at least 10 years before she was successfully scheduled for a RYGB. At the time of her procedure her weight was $166.7 \mathrm{~kg}$ (BMI $53.2 \mathrm{~kg} / \mathrm{m}^{2}$ ). She used a multiple daily injection insulin regimen. Her total daily insulin dose was 180 units ( 1.08 units $/ \mathrm{kg}$ ). Her average A1C for the year before the surgery was $8.1 \%$. At one-year post procedure, her weight decreased to $96.4 \mathrm{~kg}$ for a $42.1 \%$ weight reduction. Her insulin requirements
Table I Characteristics of patients before Roux-en-Y gastric bypass surgery

\begin{tabular}{llll}
\hline & Patient A & Patient B & Patient C \\
\hline Preoperative weight $(\mathrm{kg})$ & $\mathrm{II} 5.0$ & 110.4 & 166.7 \\
Preoperative BMI $\left(\mathrm{kg} / \mathrm{m}^{2}\right)$ & 40.6 & 43.9 & 53.28 \\
$\begin{array}{l}\text { Preoperative insulin } \\
\text { requirements (units } / \mathrm{kg})\end{array}$ & 0.57 & 0.47 & 1.08 \\
C-peptide $(\mathrm{ng} / \mathrm{mL})$ & & & \\
Average preoperative AIC (\%) & 8.2 & 7.6 & 8.1 \\
\hline
\end{tabular}

Abbreviations: AIC, glycosylated hemoglobin; BMI, body mass index.

had decreased to a total daily dose of approximately 48.2 units $(0.5$ units $/ \mathrm{kg}$ ). Her average A1C for the year after the procedure increased to $8.8 \%$ (Tables 1 and 2).

\section{Discussion}

The striking results of bariatric surgery on severely obese patients with DM2 have brought into question traditional theories on the pathogenesis and therapeutics of diabetes mellitus. Complete resolution of this chronic condition is now the norm rather than the exception in severely obese patients that undergo bariatric procedures. Extending these benefits to patients with DM1 has created significant interest in this field.

The mechanisms leading to resolution of DM2 after RGYB are not clearly understood. Growing research has offered several important facts and proposed theories to better understand this phenomenon. Different bariatric techniques achieve different rates of DM2 diabetes resolution, with the most impressive results obtained from the partial gastrectomy with distal Roux-en-Y reconstruction (RYGB) and the BPD. Common endpoints of these techniques that use bypass procedure are rapid delivery of gastric content to the distal ileum and exclusion of proximal small intestine from the food path. Rapid delivery of gastric content to the distal part of the small intestine has been associated with increased secretion of gut hormones also known as incretins. This concept also known as the hindgut theory proposes that incretins, especially glucagon-like peptide (GLP-1) and peptide YY (PYY), contribute in great part to the improved

Table 2 Characteristics of patients after Roux-en-Y gastric bypass surgery

\begin{tabular}{llll}
\hline & Patient A & Patient B & Patient C \\
\hline Postoperative weight $(\mathrm{kg})$ & 75.5 & 77.5 & 96.4 \\
Postoperative BMI $\left(\mathrm{kg} / \mathrm{m}^{2}\right)$ & 26.7 & 30.8 & 30.8 \\
$\begin{array}{l}\text { Postoperative insulin } \\
\text { requirements (units } / \mathrm{kg})\end{array}$ & 0.60 & 0.46 & 0.50 \\
Average postoperative AIC (\%) & 7.5 & 7.8 & 8.8 \\
\hline
\end{tabular}

Abbreviations: AIC, glycosylated hemoglobin; BMI, body mass index. 
metabolic control seen in the postoperative period. ${ }^{4}$ These two substances produced by the L cells of the distal ileum are known to have important metabolic actions. Given the smaller plasma concentration of GLP-1 compared to PYY, GLP-1 is considered to be more potent. Several beneficial effects have been attributed to GLP-1. Induced satiety through slow gastric emptying and action on the central nervous system has been linked to significant weight loss. More importantly, GLP-1 has been associated with increased insulin secretion by acting directly over the beta cell membrane receptors. GLP-1 also increases glycogenesis in hepatic and skeletal muscle cells. It also accelerates lipogenesis in adipocytes, which may result in improved insulin sensitivity. ${ }^{6}$ In addition, it has been shown in animal models with DM2, that GLP-1 increased beta-cell mass through regulation of proliferation, neogenesis, and apoptosis. ${ }^{7}$ This last quality of GLP-1 would suggest a hopeful scenario for patients with DM1 of whom their residual beta cell mass is mostly minimal or absent.

A different theory originally proposed by Pories and later explored by Rubino et al known as the 'foregut bypass' hypothesis, suggests that the exclusion of the duodenum and proximal jejunum from the gastrointestinal tract seems to prevent the secretion of a deleterious hormone (decretin) that could be implicated in the pathogenesis of diabetes. ${ }^{8,9}$ As to our knowledge, in despite of extensive research in this area, no substance has been identified yet.

Insulin sensitivity has been shown to notoriously improve after RYGB. Bikman et al suggested that something other than the weight loss contributed in great part for the change in insulin utilization. They proposed that improved insulin sensitivity and greater glucose transport is related to reduced inhibition of $\mathrm{\kappa B}$ kinase $\beta$ activity and enhanced insulin signaling in muscle. ${ }^{10}$

In this small series of patients with DM1 diabetes, the RYGB bariatric procedure did not appear to significantly improve glycemic control. One year after the procedure, A1C was still not at goal for any of the three patients. Insulin requirements did decrease for two patients suggesting improved insulin sensitivity, while it remained unchanged in one.

We hypothesize that the resolution of DM2 after RGYB requires significant functioning beta cells mass. In DM1 where insulin secretion is minimal or often absent, RGYB is less likely to positively impact glycemic control. Dependence of exogenous insulin therapy to achieve euglycemia precludes easily achieving optimal glycemic control in this patient population.

\section{Conclusion}

The RYGB bariatric procedure seems not to directly improve glycemic control in DM1. Achieving glycemic control is challenging in these patients even after decreasing their excess body weight and improving insulin sensitivity. Larger randomized case control studies are needed to demonstrate more definitive results.

\section{Disclosure}

No conflicts of interest were declared in relation to this paper.

\section{References}

1. Liu LL, Lawrence JM, Davis C, et al. Prevalence of overweight and obesity in youth with diabetes in USA: the SEARCH for diabetes in youth study. Pediatr Diabetes. 2010; 11(1):4-11.

2. Sjostrom L, Narbro K, Sjostrom CD, Karason K, Larsson B, Wedel H, et al. Effects of bariatric surgery on mortality in Swedish obese subjects. N Engl J Med. 2007;357(8):741-752.

3. Levy P, Fried M, Santini F, Finer N. The comparative effects of bariatric surgery on weight and type 2 diabetes. Obes Surg. 2007; 17(9):1248-1256.

4. Vetter ML, Cardillo S, Rickels MR, Iqbal N. Narrative review: effect of bariatric surgery on type 2 diabetes mellitus. Ann Intern Med. 2009;150(2):94-103.

5. Czupryniak L, Strzelczyk J, Cypryk K, Pawlowski M, Szymanski D, Lewinski A, et al. Gastric bypass surgery in severely obese type 1 diabetic patients. Diabetes Care. 2004;27(10):2561-2562.

6. Holst JJ. The physiology of glucagon-like peptide 1. Physiol Rev. 2007; 87:1409-1439.

7. Farilla L, Hui H, Bertolotto C, Kang E, Bulotta A, Di Mario U, et al. Glucagon-like peptide-1 promotes islet cell growth and inhibits apoptosis in zucker diabetic rats. Endocrinology. 2002;143(11):4397-4408.

8. Pories WJ. Why does the gastric bypass control type 2 diabetes mellitus? Obes Surg. 1992;2:303-313.

9. Rubino F. Is type 2 diabetes an operable intestinal disease? A provocative yet reasonable hypothesis. Diabetes Care. 2008;31 Suppl 2: S290-S296.

10. Bikman BT, Zheng D, Pories WJ, Chapman W, Pender JR, Bowden RC, et al. Mechanism for improved insulin sensitivity after gastric bypass surgery. J Clin Endocrinol Metab. 2008;93(12):4656-4663.

Diabetes, Metabolic Syndrome and Obesity: Targets and Therapy

\section{Publish your work in this journal}

Diabetes, Metabolic Syndrome and Obesity: Targets and Therapy is an international, peer-reviewed open-access journal committed to the rapid publication of the latest laboratory and clinical findings in the fields of diabetes, metabolic syndrome and obesity research Original research, review, case reports, hypothesis formation, expert opinion and commentaries are all considered for publication. The manuscript management system is completely online and includes a very quick and fair peer-review system, which is all easy to use. Visit http://www.dovepress.com/testimonials.php to read real quotes from published authors. 